Dry Matter Partitioning and Salt Tolerance via Salicylic Acid Treatment in Strawberry Plant Under Salt Stress

Servet $\mathrm{ARAS}^{1}$, Ahmet EŞITTKEN ${ }^{2}$

1Yozgat Bozok University, Faculty of Agriculture, Department of Horticulture, 66200, Yozgat, Turkey, 2Selcuk University, Faculty of Agriculture, Department of Horticulture, 42030, Konya, Turkey

${ }^{1}$ https://orcid.org/0000-0002-0347-6552, ${ }^{2}$ https://orcid.org/0000-0002-6140-7782

$\bowtie$ : servet.aras@bozok.edu.tr

\section{ABSTRACT}

The objective of this experiment was to investigate the effects of exogenous salicylic acid (SA) on strawberry plants under $\mathrm{NaCl}$ stress. The strawberry (Fragaria $\times$ ananassa Duch.) cv Kabarla was used in the experiment. Until the beginning of the experiment, all plants were irrigated with tap water and 1-month after planting, all plants were applied with three different SA doses (1, 2 and $4 \mathrm{mM}$ ) and were watered with $35 \mathrm{mM} \mathrm{NaCl}$ solution. Control and salt plants were not applied with $\mathrm{SA}$, salt plants were watered with $\mathrm{NaCl}$ solution and compared to controls. Three months after the salinity (in March), salt stress decreased root volume by $37 \%$ compared to control. Overall, 4 mM SA and control had the highest values of root tissue density $(0.113$ and $0.117 \mathrm{~g} \mathrm{~cm}^{-3}$, respectively). Moreover, $4 \mathrm{mM} \mathrm{SA}$ treatment increased stomatal conductance by $87 \%$ compared to salt plants. The dry matter was less partitioned to roots in salt stressed strawberry plant. Dry matter partitioning between shoots and roots was differently affected by supply of SA under salinity condition.

\section{Research Article}

$\begin{array}{ll}\text { Article History } & \\ \text { Received } & : 28.03 .2019 \\ \text { Accepted } & : 19.07 .2019\end{array}$

Keywords

Dry matter distribution,

Salicylic acid,

Salt stress,

Strawberry

\title{
Tuz Stresi Altındaki Çilek Bitkilerinde Salisilik Asit Uygulamasıyla Kuru Madde Dağılımı ve Tuz Tolerans1
}

\section{ÖZET}

Çalışmanın amacı, dışarından uygulanan salisilik asidin (SA) tuz stresi koşulu altında yetiştirilen çilek bitkilerindeki etkileri incelemektir. Kabarla çilek (Fragaria $\times$ ananassa Duch.) çeşidi çalışma için seçilmiştir. Deneme başlayana kadar tüm bitkiler musluk suyu ile sulanmıştır ve dikimden 1 ay sonra bitkilere 3 farklı dozda SA (1, 2 ve $4 \mathrm{mM}$ ) uygulanmış ve $35 \mathrm{mM} \mathrm{NaCl}$ çözeltisi verilmiştir. Kontrol ve tuz bitkilerine SA uygulanmamış olup tuz uygulanan bitkiler kontrol bitkileriyle kıyas edilmiştir. Üç aylık tuz stresi sonucunda (Mart ayında), tuz stresi kök hacmini kontrol bitkilerine kıyasla \%37 azaltmıştır. 4 mM SA ve kontrol grubu en yüksek kök yoğunluğuna (sırasıyla 0.113 ve $0.117 \mathrm{~g} \mathrm{~cm}^{-3}$ ) sahip olmuştur. Ayrıca, 4 mM SA uygulaması stoma iletkenliğini tuz bitkisine kıyasla \%87 artırmıştır. Tuz uygulaması sonucunda kuru madde köke daha az gönderilmiştir. Kök ve sürgünler arasında kuru madde dağılımı SA uygulaması ile farklı derecede etkilenmiştir.

\section{Araștırma Makalesi}

$\begin{array}{ll}\text { Makale Tarihçesi } \\ \text { Geliş Tarihi } & : 28.03 .2019 \\ \text { Kabul Tarihi } & : 19.07 .2019\end{array}$

\section{Anahtar Kelimeler}

Kuru madde dağılımı,

Salisilik asit,

Tuz stresi,

Çilek

To Cite : Aras S, Eşitken S 2019. Dry Matter Partitioning and Salt Tolerance via Salicylic Acid Treatment in Strawberry Plant Under Salt Stress. KSU J. Agric Nat 22(Suppl 2): 337-341. DOIः 10.18016/ ksutarimdoga.vi.545825

\section{INTRODUCTION}

In many areas of the world, salinity has been considerably the main constraint for crop production. High concentration of $\mathrm{NaCl}$, the dominant salt in the soil (Pessarakli and Szabolcs, 2010), diminishes fruit yield and quality in many plants (Colla et al., 2006; Huang et al., 2009). Growth reduction due to the presence of sodium chloride $(\mathrm{NaCl})$ at certain concentrations was reported in many fruit species (Aras et al., 2015; Akçay and Eşitken, 2017; Aras and Eşitken, 2018). Among these fruit species, strawberry was suggested to be salt-affected and salt stress may cause decrease in strawberry fruit yield and quality (Garriga et al., 2015). Salinity causes physiological 
dysfunctions (Yin et al., 2010), ion imbalance (Karlidag et al., 2011), depression in photosynthesis (Galli et al., 2016), leading to growth reduction (Kaya et al., 2002) and decrease in fruit quality and taste (Kaya et al., 2002; Keutgen and Pawelzik, 2008) in strawberry.

Plant growth regulator treatments were found to play an important role in plant responses to stress factors (Chakrabarti and Mukherjee, 2003). Salicylic acid (SA) plays an important role in the regulation of plant growth, development and responses to abiotic stresses (Noreen and Ashraf, 2008; Miura and Tada, 2014). Application of exogenous SA enhanced the salt stress resistance of many plants (Szepesi et al., 2009; Nazar et al., 2011). Gunes et al. (2007) found that SA treatment increased the plant growth in maize plants under salinity. In addition, some studies showed that exogenous SA could alleviate the salinity damage in strawberry (Karlidag et al., 2009; Tohma and Esitken, 2011). SA could increase chlorophyll content and maintain the stability of cell membrans, which was benefical to plant growth under salinity condition (Gunes et al., 2007; Szepesi et al., 2009).

Environmental stress factors affect dry matter partitioning between root and shoot and plant morphological traits such as root and shoot fresh and dry weights, root tissue density, root:shoot dry weight in many plants (Marschner et al., 1996; Chartzoulakis et al., 2002; Aras and Eşitken, 2018). Many studies have supported clear evidences that SA treatment ameliorates salinity stress and increases plant growth in many plants. However, evidence is scarce for dry matter distribution in strawberry plant. The objective of the this study was to assess the effect of SA on plant growth and dry matter partitioning in strawberry plant under salinity condition.

\section{MATERIALS and METHODS}

\section{Pot trials and experimental design}

The study was conducted between November of 2015 and March of 2016 in a heated greenhouse located in Department of Horticulture at Selcuk University, Konya, Turkey. Well-rooted frigo strawberry plant (Fragaria $\times$ ananassa Duch.) cv. Kabarla was used for the experiment. The experiment was a randomized plot design with three replication, three plants each. The plants were potted in $5 \mathrm{~L}$ plastic pots filled with mixture of soil, peat and perlite in a volume ratio of $1: 4: 1$. Until the beginning of the experiment, all plants were irrigated with tap water and 1-month after planting, all plants were applied with three different SA doses (1,2 and $4 \mathrm{mM}$ ) and were watered with 35 $\mathrm{mM} \mathrm{NaCl}$ solution (growing media's salinity of plants exposed salt stress maintained in a range of $2.0-2.5 \mathrm{mS}$ $\mathrm{cm}^{-1}$ EC through applying $35 \mathrm{mM} \mathrm{NaCl}$ ). SA was applied to the roots of strawberry plants for once with irrigation water. Control and salt plants were not applied with SA, salt plants were watered with $\mathrm{NaCl}$ solution. When the growing media's salinity exceeded $2.5 \mathrm{~cm}^{-1} \mathrm{EC}$ plants were irrigated with tap water and when the media's salinity was belowed the $2 \mathrm{~cm}^{-1} \mathrm{EC}$ $\mathrm{NaCl}$ solution were used for irrigation. Three months after the salinity (in March), many plant growth properties were evaluated.

\section{Growth, SPAD and Stomatal Conductance Measurements}

The growth promoting effects of SA treatments were evaluated by determination of root volume, root and shoot dry and fresh weights. Root volume was calculated by displacement of water in the volumetric cylinder. Root and shoot dry weights were measured after drying the plant material at $70^{\circ} \mathrm{C}$ for $48-72$ hours. The value of root:shoot dry weight was calculated as dry weights of root:shoot. Moreover, root volume, root mass ratio (RMR, root dry weight:whole dry weight, $g$ $\mathrm{g}^{-1}$ ), shoot mass ratio (SMR, shoot dry weight/whole dry weight, $\mathrm{g} \mathrm{g}^{-1}$ ), and root tissue density (RTD, root dry weight/root volume, $\mathrm{g} \mathrm{cm}^{-3}$ ) were calculated as reported previously (Lupini et al., 2016).

Relative chlorophyll (SPAD) value was measured with a Minolta SPAD-502 chlorophyll meter (Minolta Camera Co, Ltd, Osaka, Japan). Stomatal conductivity was conducted on the youngest fully expanded leaves on upper branches of the plants with leaf porometer.

Statistical analyses were performed with SPSS, version 20.0. The means were compared by the Duncan's Multiple Range Test te at $5 \%$ level.

\section{RESULTS}

Compared to the salt plants, SA-induced salinity tolerance was reflected in the significant alterations of root volume, root tissue density, root mass ratio, shoot mass ratio, root:shoot dry weight, SPAD value and stomatal conductance (Table 1 and 2). Salt stress decreased root volume by $37 \%$ compared to control. Overall, $4 \mathrm{mM}$ SA treament sustained the lowest root volume. On the contrary, $4 \mathrm{mM} \mathrm{SA}$ and control sustained the highest root tissue density $(0.113$ and $0.117 \mathrm{~g} \mathrm{~cm}^{-3}$, respectively). Exogenous SA increased the root mass ratio by $86 \%$ compared to salt plant. In case of non-SA condition, shoot mass ratio showed a slight change under salt stress (Table 1).

SPAD value for leaves treated with SA decreased more slowly than those non-treated salt plants (Table 2). SA treatments leaded increases in stomatal conductance under salt stress. Moreover, $4 \mathrm{mM}$ SA treatment increased stomatal conductance by $87 \%$ compared to salt plants.

\section{DISCUSSION}

Salt stress affects the morphological and physiological characteristics of plants due to physiological disruptions, nutrient imbalance, chlorophyll loss (Yin 
et al., 2010; Aras and Eşitken, 2018). In the current study, we investigated the ameliorative effects of exogenous SA on strawberry growth under salinity condition. Compared to salt plants, many growth traits were manifested as a significant decrease as a result of salinity and alleviated by SA treatment. The change trend between morphological characteristics was more obvious when SA concentration was $4 \mathrm{mM}$.

Table 1. Effect of SA on root volume, root tissue density, root and shoot mass ratio and root:shoot dry weight in salt-treated strawberry plants

\begin{tabular}{llllll}
\hline & $\begin{array}{l}\text { Root volume } \\
\left(\mathrm{cm}^{3}\right)\end{array}$ & $\begin{array}{l}\text { Root tissue density } \\
\left(\mathrm{g} \mathrm{cm}^{-3}\right)\end{array}$ & $\begin{array}{l}\text { Root mass } \\
\text { ratio }\left(\mathrm{g} \mathrm{g}^{-1}\right)\end{array}$ & $\begin{array}{l}\text { Shoot mass } \\
\text { ratio }\left(\mathrm{g} \mathrm{g}^{-1}\right)\end{array}$ & $\begin{array}{l}\text { Root:shoot } \\
\text { dry weight }\end{array}$ \\
\hline Control & $45.0 \mathrm{a}$ & $0.117 \mathrm{a}$ & $0.269 \mathrm{ab}$ & $0.730 \mathrm{a}$ & $0.370 \mathrm{~b}$ \\
Salt & $28.3 \mathrm{~b}$ & $0.077 \mathrm{~b}$ & $0.211 \mathrm{~b}$ & $0.771 \mathrm{a}$ & $0.280 \mathrm{e}$ \\
SA $(1 \mathrm{mM})+$ Salt & $28.7 \mathrm{~b}$ & $0.076 \mathrm{~b}$ & $0.227 \mathrm{~b}$ & $0.772 \mathrm{a}$ & $0.288 \mathrm{c}$ \\
SA $(2 \mathrm{mM})+$ Salt & $29.0 \mathrm{~b}$ & $0.077 \mathrm{~b}$ & $0.224 \mathrm{~b}$ & $0.775 \mathrm{a}$ & $0.285 \mathrm{~d}$ \\
SA $(4 \mathrm{mM})+$ Salt & $20.0 \mathrm{c}$ & $0.113 \mathrm{a}$ & $0.393 \mathrm{a}$ & $0.606 \mathrm{~b}$ & $0.637 \mathrm{a}$ \\
\hline
\end{tabular}

Means separation within column by Duncan's multiple range test, $P<0.05$

Table 2. Effect of SA on SPAD and stomatal conductance in salt-treated strawberry plants

\begin{tabular}{llc}
\hline & SPAD & $\begin{array}{c}\text { Stomatal Conductance } \\
\left(\mathrm{mmolm}^{-2} \mathrm{~s}^{-1}\right)\end{array}$ \\
\hline Control & $45.46 \mathrm{a}$ & $111.6 \mathrm{bc}$ \\
Salt & $38.40 \mathrm{~b}$ & $102.83 \mathrm{c}$ \\
SA $(1 \mathrm{mM})+$ Salt & $41.73 \mathrm{ab}$ & $180.93 \mathrm{ab}$ \\
$\mathrm{SA}(2 \mathrm{mM})+$ Salt & $39.62 \mathrm{~b}$ & $148.93 \mathrm{abc}$ \\
SA $(4 \mathrm{mM})+$ Salt & $39.86 \mathrm{~b}$ & $192.30 \mathrm{a}$ \\
\hline
\end{tabular}

Means separation within column by Duncan's multiple range test, $P<0.05$

Root tissue density reflects root functional status that is associated with physiological activities in plant body (Wahl and Ryser 2000; Ostonen et al., 2007). The tissue density is affected by cell wall material, lignin and percentage of air space (Koike, 1988; Garnier and Laurent, 1994). In our study, $4 \mathrm{mM} \mathrm{SA}$ increased root tissue density, although the lowest root volume was in $4 \mathrm{mM}$ SA treatment. Low tissue density enables a fast growth rate with a low investment on dry matter (Hummel et al. 2007). Some studies showed that higher root respiration result in decrease in dry matter accumulation in roots, which, in turn, leads to decrease in root tissue density (Wardlaw, 1990; Masoni et al., 2007). In the current experiment, salt stress decreased root tissue density when compared with control may be due to increase in root respiration triggered by salt stress. High density tissue leads a better protection against adverse environment with a high investment on dry matter (Pammenter et al., 1986). Thus, SA treatment provided better root growth via dry matter partitioning to roots.

SA treatments increased root:shoot dry weight in strawberry. Root:shoot dry weight was about 2 -fold by $4 \mathrm{mM}$ SA treatment to that of control plants. In a previous study it was reported that acquisition of necessary nutritions for photosynthesis such as nitrogen and Sulphur could be performed by SA treatment and photosynthesis increases (Nazar et al., 2011). In our experiment, increase in root:shoot dry weight by $4 \mathrm{mM}$ SA might be attributed to increment in photosynthesis and then higher transport and use of photoasimilates in the roots.

Decrease in the root mass ratio was more obvious in salt plants as compared to the controls. Moreover, there was a slight decrease in shoot mass ratio. These changes show that shoot growth was less affected than root growth. This finding confirms the evidence regarding the effect of salinity on root by decreasing root:shoot dry weight under salt stress. Therefore, salinity in strawberry may alter the pattern of dry matter distribution favoring the shoot. Apparently, salt stressed strawberry plants partitioned more carbon to the shoots during salt stress period.

Chlorophyll (SPAD value) content was significantly decreased by $35 \mathrm{mM} \mathrm{NaCl}$ treatment. Similarly, Tohma and Esitken (2011) also reported that chlorophyll content was decreased by salt stress in strawberry. Salt stress damages cell membrane and causes the leakage of chlorophyll molecules and declines chlorophyll content (Mehta et al., 2010). Furthermore, decline in chlorophyll content could be due to an increase in the chlorophyll degradation (Eldesouky and Atawia, 1998). In our experiment, there are considerable preventions of the chlorophyll reductions by SA compared to salt plant. Szepesi et al. (2009) also reported SA treatment prevented the chlorophyll loss in tomato plants under salinity condition. Moreover, SA treatment increased stomatal conductance under salinity. Stomatal conductance recorded on plants treated with $4 \mathrm{mM}$ SA was $87 \%$ higher than those recorded in salt plants. Reduction in stomatal conductance was due mainly to an increase in $\mathrm{Na}^{+}$content (Zrig et al., 2011). A protective effect of SA on stomata was reported under salt stress in many studies (Nazar et al., 2011).

\section{CONCLUSION}

SA treated plants sustained better growth and this may be attributed more chlorophyll and stomatal conductance compared to salt stressed plant. The 
interpretation of the presented data indicated that the dry matter was less partitioned to roots in salt stressed strawberry plant and more allocated in leaves compared to control. Dry matter partitioning between shoots and roots was differently affected by supply of SA under salinity condition. Root tissue density and root:shoot dry weight could be used as indices of dry matter partitioning between root and shoots. In conclusion, our data show that SA, especially $4 \mathrm{mM}$ dose, provided the dry matter distribution to roots and decreased the adverse effects of salt stress in strawberry plant growth.

\section{REFERENCES}

Akçay D, Eşitken A 2017. MM106 Anacı ve Üzerine Aşılı Golden Delicious Elma Çeşidine Tuz Stresinin Etkileri. Selçuk Tarım Bilimleri Dergisi, 3(2): 228232.

Aras S, Arslan E, Esitken A 2015. Biochemical and Physiological Responses of Lemon Plant Under Salt Stress. 2nd International Conference on Sustainable Agriculture and Environment, , 30 September-3 October 2015, Konya.

Aras S, Eşitken A 2018. Physiological Responses of Cherry Rootstocks to Short Term Salinity. ErwerbsObstbau, 60: 161-164.

Chakrabarti N, Mukherjee S 2003. Effect of Phytohormones Pretreatment on Nitrogen Metabolism in Vigna radiata Under Salt Stress. Biologia Plantarum, 36: 63-66.

Chartzoulakis K, Loupassaki M, Bertaki M, Androulakis I 2002. Effects of $\mathrm{NaCl}$ Salinity on Growth, Ion Content and $\mathrm{CO}_{2}$ Assimilation Rate of Six Olive Cultivars. Scientia Horticulturae, 96(1-4): 235-247.

Colla G, Roupahel Y, Cardarelli M, Rea E 2006. Effect of Salinity on Yield, Fruit Quality, Leaf Gas Exchange, and Mineral Composition of Grafted Watermelon Plants. HortScience, 41(3): 622-627.

El-Desouky SA, Atawia AAR 1998. Growth Performance of Some Citrus Rootstocks Under Saline Conditions. Alexandria Journal of Agricultural Research, 43: 231-254.

Galli V, da Silva Messias R, Perin EC, Borowski JM, Bamberg AL, Rombaldi CV 2016. Mild Salt Stress Improves Strawberry Fruit Quality. LWT-Food Science And Technology, 73: 693-699.

Gamier E, Laurent G 1994. Leaf Anatomy, Specific Mass and Water Content In Congeneric Annual and Perennial Grass Species. New Phytologist, 128: 725-736.

Garriga M, Muñoz CA, Caligari PD, Retamales JB 2015. Effect of Salt Stress on Genotypes of Commercial (Fragaria X ananassa) and Chilean Strawberry ( $F$. chiloensis). Scientia Horticulturae, 195: 37-47.

Gunes A, Inal A, Alpaslan M, Eraslan F, Bagci EG, Cicek N 2007. Salicylic Acid Induced Changes on
Some Physiological Parameters Symptomatic For Oxidative Stress and Mineral Nutrition In Maize (Zea mays L.) Grown Under Salinity. Journal of Plant Physiology, 164(6): 728-736.

Huang Y, Tang R, Cao Q, Bie Z 2009. Improving the Fruit Yield and Quality of Cucumber by Grafting onto the Salt Tolerant Rootstock Under $\mathrm{NaCl}$ Stress. Scientia Horticulturae, 122(1): 26-31.

Hummel I, Vile D, Violle C, Devaux J, Ricci B, Blanchard A, Garnier E, Roumet C 2007. Relating Root Structure and Anatomy to Whole-Plant Functioning In 14 Herbaceous Mediterranean Species. The New Phytologist, 173: 313-21.

Karlidag H, Yildirim E, Turan M 2009. Salicylic Acid Ameliorates the Adverse Effect of Salt Stress on Strawberry. Scientia Agricola, 66(2): 180-187.

Karlidag H, Yildirim E, Turan M 2011. Role of 24Epibrassinolide In Mitigating the Adverse Effects of Salt Stress on Stomatal Conductance, Membrane Permeability, and Leaf Water Content, Ionic Composition In Salt Stressed Strawberry (Fragaria× ananassa). Scientia Horticulturae, 130(1): 133-140.

Kaya C, Kirnak H, Higgs D, Saltali K 2002. Supplementary Calcium Enhances Plant Growth and Fruit Yield In Strawberry Cultivars Grown at High ( $\mathrm{NaCl})$ Salinity. Scientia Horticulturae, 93(1): 65-74.

Keutgen AJ, Pawelzik E 2008. Quality and Nutritional Value of Strawberry Fruit Under Long Term Salt Stress. Food Chemistry, 107(4): 1413-1420.

Koike T 1988. Leaf Structure and Photosynthetic Performance as Related to the Forest Succession of Deciduous Broad-Leaved Trees. Plant Species Biology, 3: 77-87.

Lupini A, Sorgonà A, Princi MP, Sunseri F, Abenavoli MR 2016. Morphological and Physiological Effects of Trans-Cinnamic Acid and Its Hydroxylated Derivatives on Maize Root Types. Plant Growth Regulation, 78: 263-273.

Marschner H, Kirkby EA, Cakmak I 1996. Effect of Mineral Nutritional Status on Shoot-Root Partitioning of Photoassimilates and Cycling of Mineral Nutrients. Journal of Experimental Botany, 47: 1255-1263.

Masoni A, Ercoli L, Mariotti M, Arduini I 2007. PostAnthesis Accumulation and Remobilization of Dry Matter, Nitrogen and Phosphorus in Durum Wheat as Affected by Soil Type. European Journal of Agronomy, 26(3): 179-186.

Mehta P, Jajoo A, Mathur S, Bharti S 2010. Chlorophyll a Fluorescence Study Revealing Effects of High Salt Stress on Photosystem II in Wheat Leaves. Plant Physiology and Biochemistry, 48: 1620.

Miura K, Tada Y 2014. Regulation of Water, Salinity, and Cold Stress Responses by Salicylic Acid. Frontiers in Plant Science, 5: 1-12. 
Nazar R, Iqbal N, Syeed S, Khan NA 2011. Salicylic Acid Alleviates Decreases in Photosynthesis Under Salt Stress by Enhancing Nitrogen and Sulfur Assimilation and Antioxidant Metabolism Differentially in Two Mungbean Cultivars. Journal of Plant Physiology, 168(8): 807-815.

Noreen S, Ashraf M 2008. Alleviation of Adverse Effects of Salt Stress on Sunflower (Helianthus annuus L.) by Exogenous Application of Salicylic Acid: Growth and Photosynthesis. Pakistan Journal of Botany, 40(4): 1657-1663.

Ostonen I, Lõhmus K, Helmisaari HS, Truu J, Meel S 2007. Fine Root Morphological Adaptations in Scots Pine, Norway Spruce and Silver Birch along a Latitudinal Gradient in Boreal Forests. Tree Physiology, 27(11): 1627-1634.

Pammenter NW, Drennan PM, Smith VR 1986. Physiological and Anatomical Aspects of Photosynthesis of Two Agrostis Species at a SubAntarctic Island. New Phytologist, 102: 143-160.

Pessarakli M, Szabolcs I 2010. Soil Salinity and Sodicity as Particular Plant/Crop Stress Factors. In: Pessarakli, M. (Ed.), Handbook of Plant and Crop Stress, thirded. CRC Press, Boca Raton, pp: 321.
Szepesi Á, Csiszár J, Gémes K, Horváth E, Horváth F, Simon ML, Tari I 2009. Salicylic Acid Improves Acclimation to salt stress by Stimulating Abscisic Aldehyde Oxidase Activity and Abscisic Acid Accumulation, and Increases $\mathrm{Na}^{+}$Content in Leaves without Toxicity Symptoms in Solanum lycopersicum L. Journal of Plant Physiology, 166(9): 914-925.

Tohma O, Esitken A 2011. Response of Salt Stressed Strawberry Plants to Foliar Salicylic Acid PreTreatments. Journal of Plant Nutrition, 34(4): 590599.

Wahl S, Ryser P 2000. Root Tissue Structure is Linked to Ecological Strategies of Grasses. New Phytologist, 148:459-471.

Wardlaw IF 1990. The Control of Carbon Partitioning in Plants. New Phytologist, 116(3): 341-381.

Yin R, Bai T, Ma F, Wang X, Li Y, Yue Z, 2010. Physiological Responses and Relative Tolerance by Chinese Apple Rootstocks to $\mathrm{NaCl}$ Stress. Scientia Horticulturae, 126: 247-252.

Zrig A, Tounekti T, Vadel AM, BenMohamed H, Valero D, Serrano M, Chtara C, Khemira H 2011. Possible Involvement of Polyphenols and Polyamines in Salt Tolerance of Almond Rootstocks. Plant Physiology and Biochemistry, 49: 1313-1320. 